\title{
5,6-Dihydropyrrolo[2,1-a]isoquinolines as Alternative of New Drugs with Cytotoxic Activity
}

\author{
Rosa María Chávez-Santos, ${ }^{a}$ Paul Eduardo Reyes-Gutiérrez, ${ }^{b}$ Rubén Omar Torres-Ochoa, ${ }^{a}$ \\ María Teresa Ramírez-Apan, ${ }^{a}$ and Roberto Martínez*,a \\ ${ }^{a}$ Instituto de Química, Universidad Nacional Autónoma de México, Circuito Exterior, Ciudad Universitaria; 04510, \\ Cd. México, México: and ${ }^{b}$ Institute of Organic Chemistry and Biochemistry, Czech Academy of Sciences; Flemingovo \\ náměstí 542/2, 16610 Prague 6, Czech Republic.
}

Received May 17, 2017; accepted July 7, 2017; advance publication released online July 22, 2017

In this study, the pyrrolo[2,1-a]isoquinolines $4 a-n$ were synthesized in good yields in a three steps synthesis from the corresponding $\alpha, \beta$-unsaturated esters starting materials. These compounds were tested on six human cancer cells lines to measure the cytotoxic activity as a function of the electronic properties and aromaticity of the substituent at the $\mathrm{C}-2$ position of the pyrroloisoquinoline. Our results reveal that the cytotoxic activity could be explained in terms of the distribution of electronic density across the ring joined to C-2. Also, this study identified 3-hydroxy (4d) and 3-chloro (4j) derivatives with powerful cytotoxic activities. The $\mathrm{IC}_{50}$ values of these compounds were found to be comparable to those of the commercially available Topotecan, Irinotecan, Etoposide, Tamoxifen, and Cisplatin.

Key words pyrrolo[2,1-a]isoquinoline; synthesis; cytotoxic activity

Cancer is a leading cause of death worldwide, and according to the World Cancer Research Fund International (GLOBOCAN 2012), an estimated 17.1 million new cancer cases and 10.0 million cancer-related deaths will occur in 2020, compared with 15.2 million and 8.9 million, respectively, in 2015. ${ }^{1)}$ The most commonly diagnosed cancers worldwide are cancers of the skin (melanoma), prostate, lung, breast, and colorectum. ${ }^{2)}$ Cancer poses a challenge to researchers searching for potent drugs that are capable of controlling cancer growth while minimizing side effects or the development of drug resistance. Our group is currently engaged in a program aimed at synthesizing novel heterocyclic compounds that inhibit the growth of cancer cells. We recently synthesized the pyrroloisoquinolines $\mathbf{I}-\mathbf{I V}^{3,4)}$ (Table 1) in a threestep protocol, and their cytotoxic activities were tested on six tumor cell lines: PC-3 (human prostatic adenocarcinoma), U-251 (human glioblastoma), K-562 (human chronic myelogenous leukemia), HCT-15 (human colorectal adenocarcinoma), MCF-7 (human mammary adenocarcinoma), and SKLU-1 (human lung adenocarcinoma). The results of this study (Table 1), allowed us to establish preliminary structure-activity relationship (Fig. 1) that revealed the importance of the aromatic substituent at the C-2 position, particularly when the substituent was a $m$-(cyclohexylmethylpiperazinamide)phenyl (I), phenyl (II), or $m$-(amino)phenyl (III), substituent, in combination with an ethyl ester at the $\mathrm{C}-1$ position. Following up on these preliminary structure-activity studies, the present work sought to synthesize the novel pyrroloisoquinolines $4 \mathbf{a}-\mathbf{c}$ (Fig. 2) to evaluate the effects of modifying the cyclohexylmethylpiperazinyl moiety on the antiproliferative activity. Compounds $4 \mathbf{d}-\mathbf{k}$ (Fig. 2) were evaluated to determine the role of the phenyl ring substituent on the antiproliferative activity of the compound. Compounds $4 \mathbf{l}-\mathbf{n}$ (Fig. 2) were evaluated to determine the effect of modifying the aromaticity of the C-2 substituent on the antiproliferative activity.

\section{Results and Discussion}

Chemistry The synthetic route to compounds $\mathbf{4 a}-\mathbf{n}$ is depicted in Chart 1. Compounds $\mathbf{4 a}-\mathbf{n}$ were synthetized via a three-step procedure starting from $\alpha, \beta$-unsaturated esters

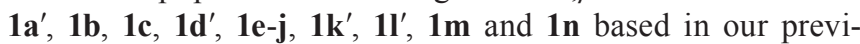
ous synthetic strategy for synthesis of 5,6-pyrrolo[2,1-a]isoquinolines I-IV with slightly modifications. ${ }^{3,4)}$ According with our synthetic Chart 1, the reaction between the corresponding aromatic aldehydes and ethyl diethylphosphonoacetate, using a Horner-Wadsworth protocol ${ }^{5)}$ gave the starting materials $\mathbf{1 c}, \mathbf{1} \mathbf{d}^{\prime}, \mathbf{1 e}-\mathbf{j}, \mathbf{1} \mathbf{l}^{\prime}, \mathbf{1} \mathbf{m}$, and $\mathbf{1 n}$ in excellent yields (Chart 2). The ethyl cinnamates $\mathbf{1} \mathbf{a}^{\prime}$ and $\mathbf{1} \mathbf{b}$ were obtained from $m$-iodobenzoic acid or $m$-iodoaniline through a Heck reaction $^{6)}$ and a subsequent amidation reaction ${ }^{7)}$ with the corresponding cyclic amines (Chart 3). It should be noted that all the $\alpha, \beta$-unsaturated esters prepared were obtained exclusively as the $(E)$-isomers in good yields $(78-98 \%)$.

Treatment of the electrophilic alkenes $1 \mathbf{a}^{\prime}-\mathbf{n}$ with monomethylated $p$-toluenesulfonylmethyl isocyanide (TosMIC), prepared from the commercially available TosMIC under phase transfer conditions according to van Leusen's proto$\operatorname{col}^{8}{ }^{8)}$ afforded the 2,3,4-polysubstituted pyrroles $\mathbf{2} \mathbf{a}^{\prime}-\mathbf{n}$ in $70-96 \%$ yields. The key intermediates $3 \mathbf{a}^{\prime}-\mathbf{n}$ were prepared by $N$-alkylation of the pyrroles $2 \mathbf{a}^{\prime}-\mathbf{n}$ using 2-bromo-4,5-dimethoxyphenethyl 4-methylbenzenesulfonate as alkylating agent, which had been prepared from 2-(3,4-dimethoxyphenyl)ethanol in the presence of sodium hydride $(\mathrm{NaH})$ as a base in dry dimethyl sulfoxide (DMSO). Finally, the $\mathrm{N}$ alkyl-pyrroles $\mathbf{3} \mathbf{a}^{\prime}-\mathbf{n}$ were cyclized to the corresponding tetrasubstituted-5,6-dihydropyrroloisoquinolines $\mathbf{4 a - n}$ using radical oxidative conditions in the presence of tributyltin hydride $\left(n-\mathrm{Bu}_{3} \mathrm{SnH}\right)$ and dilauroyl peroxide (DLP) in toluene. ${ }^{9}$ The nitro derivative was prepared via a palladium-catalyzed reaction $^{10)}$ used to obtain the tricyclic framework $4 \mathrm{~g}$. This step was necessary due to the possibility of a denitration reaction in the presence of tributyltin hydride (Chart 1, conditions iii'). 
Table 1. The $\mathrm{IC}_{50}$ Values (mм) of Compounds $\mathbf{I}$ to $\mathbf{I V}$ in the Six Cancer Cell Lines ${ }^{a)}$<smiles>CCOC(=O)c1c(-c2cccc(C(=O)N3CCN(C4CCCCC4)CC3)c2)c(C)n2c1-c1cc(OC)c(OC)cc1CC2</smiles>

I<smiles>COC(=O)c1c(-c2ccccc2)c(C)n2c1-c1cc(OC)c(OC)cc1CC2</smiles>

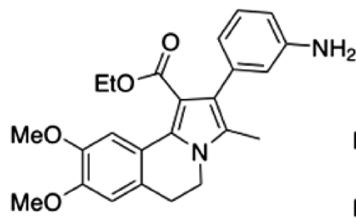

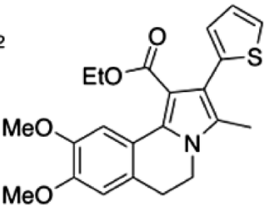

\begin{tabular}{|c|c|c|c|c|c|c|}
\hline & 1 & & & III & IV & \\
\hline Compd. & PC-3 Prostate & $\mathrm{U}-251$ (CNS) & K-562 (Leukemia) & HCT-15 (Colon) & MCF-7 (Breast) & SKLU-1 (Lung) \\
\hline I & $0.16 \pm 0.01$ & $0.05 \pm 0.00$ & $0.16 \pm 0.01$ & $0.02 \pm 0.01$ & $5.58 \pm 0.04$ & $0.02 \pm 0.00$ \\
\hline II & $18.15 \pm 0.60$ & $4.86 \pm 0.60$ & $76.78 \pm 7.30$ & $0.14 \pm 0.06$ & $25.20 \pm 2.00$ & $0.59 \pm 0.00$ \\
\hline III & $21.20 \pm 1.20$ & $5.96 \pm 0.50$ & $2.50 \pm 0.80$ & $0.01 \pm 0.00$ & $1.30 \pm 0.10$ & $0.10 \pm 0.01$ \\
\hline IV & $8.47 \pm 0.23$ & $6.99 \pm 0.67$ & $4.07 \pm 0.49$ & $0.59 \pm 0.05$ & $7.41 \pm 0.09$ & $2.13 \pm 0.03$ \\
\hline
\end{tabular}

a) Results are expressed as $\mathrm{IC}_{50}$ values in units of $\mu \mathrm{M} \pm$ standard error (S.E.). The values indicate the mean calculated from experiments conducted in triplicate.<smiles>[R]c1c(C(=O)OCC)c2n(c1C)SCc1cc(OC)c(OC)cc1-2</smiles>

Pyrrolo[2,1-a]isoquinoline scaffold

$\mathbf{R}=$

Preliminary SAR

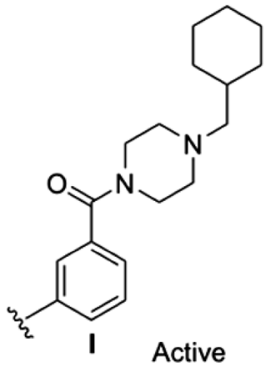<smiles>C=Ic1ccccc1CC</smiles>

Active<smiles>C#CCc1cccc(N)c1</smiles>

Active

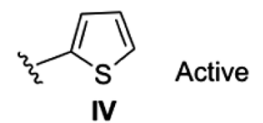<smiles>CCc1cccc(C(=O)N2CCNCC2)c1</smiles><smiles>Cc1cccc(C(=O)N2CCOCC2)c1</smiles><smiles>Cc1cccc(C(N)=O)c1</smiles><smiles>[X]c1cccc(C)c1</smiles>

$\mathrm{X}=\mathrm{OH}, \mathrm{OMe}, \mathrm{CN}, \mathrm{NO}_{2}, \mathrm{CF}_{3}, \mathrm{~F}, \mathrm{Cl}, \mathrm{Br}$

Fig. 1. Preliminary SAR of Pyrroloisoquinolines I-IV and Designed Compounds 
The piperazinyl compound $\mathbf{4 a}$ was prepared from compound $\mathbf{4} \mathbf{a}^{\prime}$ in ethanol using hydrazine hydrate as a deformylating agent. ${ }^{11)}$ The pyrroloisoquinoline $\mathbf{4 d}$ was prepared after hydrogenolysis of the benzyl ether $\mathbf{4} \mathbf{d}^{\prime}{ }^{12)}$ The bromo derivative 4k was synthesized through a Sandmeyer reaction ${ }^{13)}$ using the corresponding aniline $\mathbf{4} \mathbf{k}^{\prime}$ as a precursor. Finally, the $\mathrm{N}$ deprotection of pyrrole $\mathbf{4} \mathbf{I}^{\prime}$ was achieved after applying the reductive conditions described by Sajiko et al., ${ }^{14)}$ which afforded the pyrroloisoquinoline $\mathbf{4 l}$.

Cytotoxic Activity and Structure-Activity Relationship (SAR) for Compounds $\mathbf{4 a}-\mathbf{m}$ We evaluated the effects of modifying the cyclohexylmethylpiperazinyl group in compound I on the antiproliferative activities (Table 2). The removal of the methylcyclohexyl group from our lead compound I decreased the antiproliferative activity of the synthesized compound $\mathbf{4 a}$ in all cell lines compared to the activity of the lead compound I [Table 2, Entry 3]. These results suggested that the methylcyclohexyl group is key to the cytotoxic activity. The influence of the piperazine NH group on the activity of $4 \mathbf{a}$ was examined by synthesizing the morpholinyl analog 4b. Surprisingly, $\mathbf{4 b}$ did not inhibit proliferation of any of the six cancer lines tested (Table 2, Entry 4). On the other hand, the antiproliferative activity of $N$-formylpiperazine $\mathbf{4 \mathbf { a } ^ { \prime }}$ displayed inhibition levels minor to those displayed by $\mathbf{4 a}$. These results could be attributed to effect of the piperazinyl-NH group of $\mathbf{4 a}$ on the activity, probably by forming a quaternary ammonium ion in situ.

Complete removal of the piperazine ring, in compound $\mathbf{4 c}$ $\left(3-\mathrm{CONH}_{2}\right)$, provided a level of growth inhibition in all cell lines tested that exceeded the inhibitory activity of $\mathbf{4 a}$. The antiproliferative activity of $\mathbf{4 c}$ was better than that of the lead compound $\mathbf{I}$ in the MCF-7 cell line but lesser than in tested: PC-3, U-251, K-562, HCT-15 and SKLU-1 cell lines. The last results suggested that the electronic properties of amide group of compound (4c) affected the cytotoxicity to a greater degree than the electronic properties of cyclohexylmethyl-piperazinyl group on I in the MCF-7 cancer cell line.

The electronic effects were further examined by introducing electron-donating groups $(\mathbf{4 d}, 3-\mathrm{OH} ; \mathbf{4 e}, 3-\mathrm{OMe})$ or electron-withdrawing groups $\left(\mathbf{4 f}, 3-\mathrm{CN} ; \mathbf{4 g}, 3-\mathrm{NO}_{2} ; \mathbf{4 h}, 3-\mathrm{CF}_{3}\right)$ at the meta position of the 2-benzene ring. The majority of these changes significantly increased the inhibitory activity compared to the unsubstituted compound II in all cell lines (Table 3). By the contrary, the inhibitory activity of compounds $\mathbf{4 d - h}$<smiles>[R]c1c(C(=O)OCC)c2n(c1C)CCc1cc(OC)c(OC)cc1-2</smiles><smiles>Cc1cccc(C(=O)N2CCOCC2)c1</smiles>

Fig. 2. Proposed Compounds to Be Synthesized and Evaluated to Determine the Activity Effects of the Structural Modifications Relative to the Activities of Structures I-IV 
<smiles>[R]C=CC(=O)OCC(C)I</smiles><smiles>[R]c1c(C(=O)OCC)cn(CCc2cc(OC)c(OC)cc2Br)c1C</smiles>

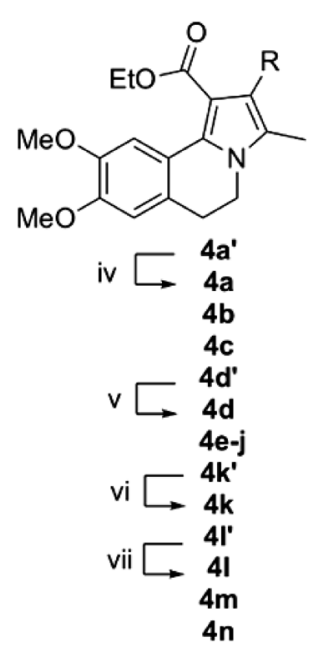<smiles>[Y]c1cccc(C(=O)N2CCOCC2)c1</smiles>

d')<smiles>Cc1cccc(Cc2ccccc2)c1</smiles>

d)<smiles>Cc1cccc(O)c1</smiles>

e)<smiles>COc1cccc(C)c1</smiles>
f)<smiles>Cc1cccc(C#N)c1</smiles>

h)<smiles>Cc1cccc(C(F)(F)F)c1</smiles>

k)<smiles>CCc1cccc(Br)c1</smiles>

m)<smiles>C[C]c1ccco1</smiles>

n)<smiles>Cc1cccc(F)c1</smiles>

j)<smiles>Cc1cccc(Cl)c1</smiles>

I')

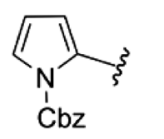<smiles>Cc1ccc[nH]1</smiles>

Reagents and conditions: (i) $\mathrm{NaH}, \mathrm{CH}_{3}$-TosMIC, diethyl ether-DMSO (2:1), $0^{\circ} \mathrm{C}$ to RT.; (ii) NaH, DMSO, 2-bromo-4,5-dimethoxyphenethyl 4-methylbenzenesulfonate, $\mathrm{RT}$; (iii) $n$ - $\mathrm{Bu}_{3} \mathrm{SnH}$, DLP, Toluene, reflux; (iii') $\mathrm{Pd}(\mathrm{OAc})_{2}, \mathrm{PPh}_{3}, \mathrm{Et}_{3} \mathrm{~N}, \mathrm{CH}_{3} \mathrm{CN}$, reflux; (iv) Hydrazine/EtOH, 60 ${ }^{\circ} \mathrm{C}$; (v, vii) $\mathrm{H}_{2}, \mathrm{Pd} / \mathrm{C} \mathrm{EtOH}, \mathrm{RT}$; (vi) $t$-BuONO, $\mathrm{CuBr}{ }_{2}$, $\mathrm{CH}_{3} \mathrm{CN}, 0^{\circ} \mathrm{C}$.

Chart 1. Synthetic Route of Compounds $\mathbf{4 a}-\mathbf{n}$

was lesser than that the lead compound $\mathbf{I}$ in all cell lines, with exception in HCT-15 cell line were compound 4d was twice times more active than I. Interestingly, compound 4d (3-OH) was the most active derivative across three of the six cancer lines (Table 3). The nature of the $-\mathrm{OH}$ substituent appeared to increase the activity due to the capacity of the substituent to form hydrogen bonds.

The roles of the electronegativity and/or size of the halogen group on the antiproliferative activity were investigated by synthesizing compounds $\mathbf{4 i}(3-\mathrm{F}), \mathbf{4 j}(3-\mathrm{Cl})$, and $\mathbf{4 k}(4-\mathrm{Br})$. As shown in Table 3 , the chloro derivative $\mathbf{4} \mathbf{j}$ was the most active of the halogenated compounds on all the cancer cell lines tested but was lesser than that the lead compound I, with exception in MCF-7 cell line were compound $\mathbf{4} \mathbf{j}$ was six times more active than $\mathbf{I}$. These results suggest that derivatization of C-2-phenyl group with an $m$-chloro substituent is suitable to obtain best anticancer pyrroloisoquinoline compounds.

Finally, the noteworthy results that have been obtained by studying bioisosteric compounds ${ }^{15}$ ) led us to synthesize bioisosters of II by changing the benzene ring to a pyrrolo, a furan or a pyridine ring, creating compounds $4 \mathbf{1}, \mathbf{4 m}$, and 4n, respectively. Our results demonstrate that a bioisosteric modification of the $\mathrm{C}-2$ benzene ring of compound II, gives compounds with preserved cytotoxic activity. Moreover, this activity is enhanced by the presence of a furan ring in the PC-3 cell line (compound 4m). However, the inhibitory activ- 


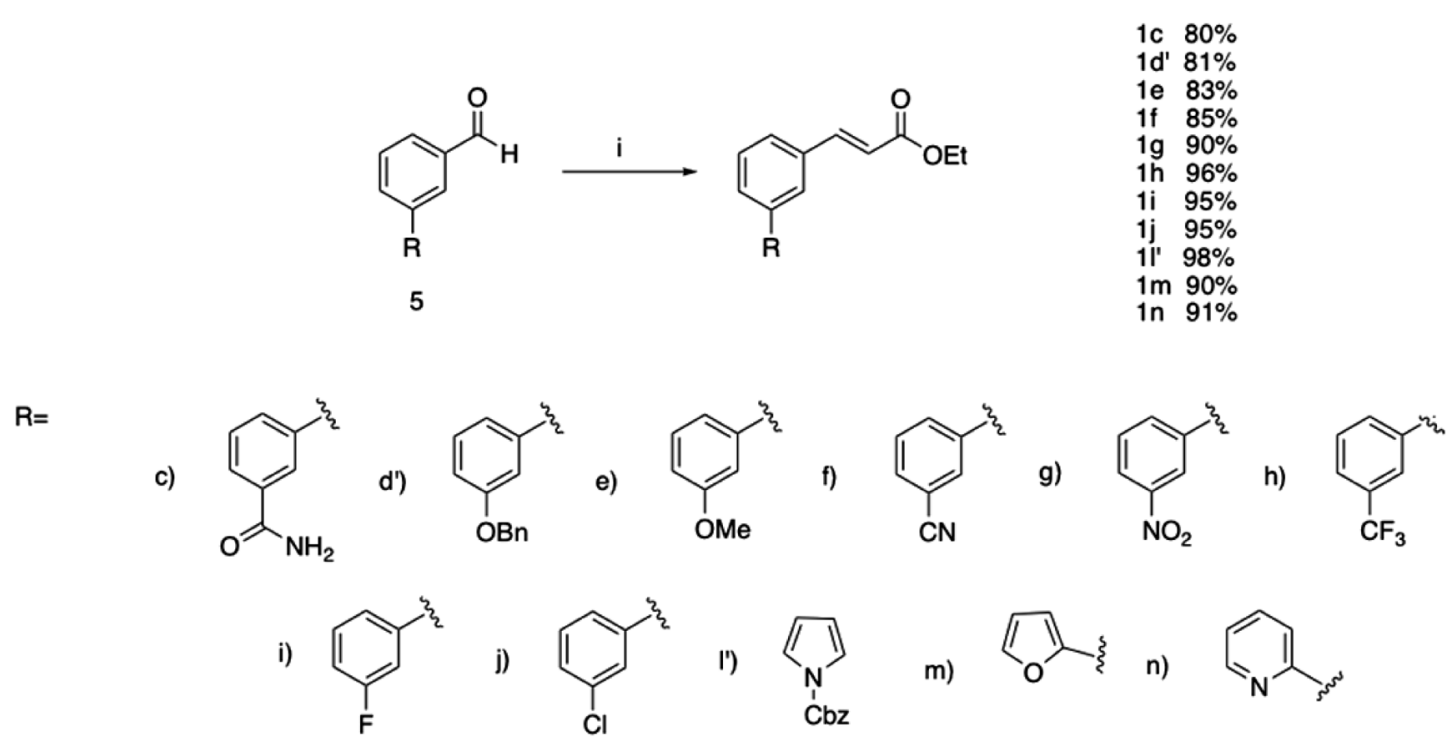

Reagents and conditions: (i) ethyl 2-(diethoxyphosphoryl)acetate, $\mathrm{NaH}, \mathrm{DMF}-60^{\circ} \mathrm{C}$.

Chart 2. Synthetic Route to the Starting Compounds $\mathbf{1 c}, \mathbf{1 d}^{\prime}, \mathbf{1 e}-\mathbf{j}, \mathbf{1} \mathbf{l}^{\prime}, \mathbf{1 m}$, and $\mathbf{1 n}$

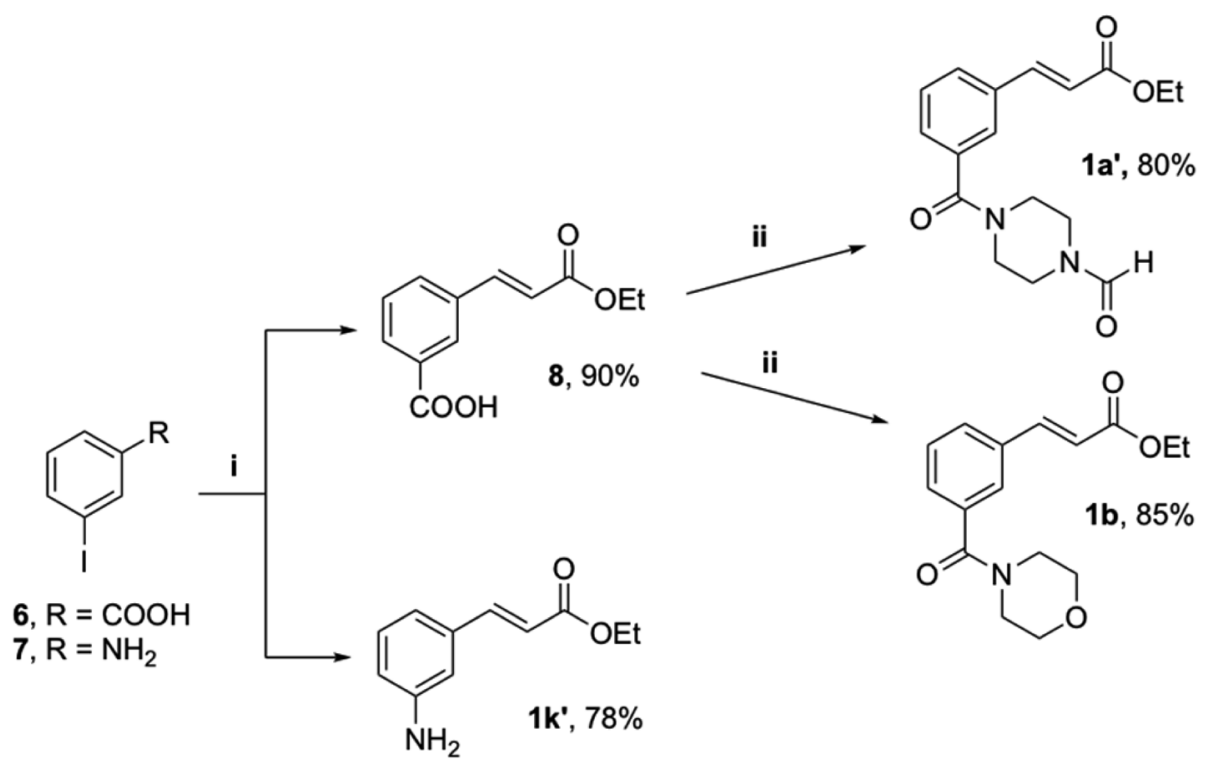

Reagents and conditions: (i) ethyl acrylate, $\mathrm{Pd}(\mathrm{OAc})_{2}, \mathrm{PPh}_{3}, \mathrm{Et}_{3} \mathrm{~N}, \mathrm{CH}_{3} \mathrm{CN}$, reflux; (ii) DCC, DCM, amine, RT.

Chart 3. Synthetic Route to Compounds $\mathbf{1} \mathbf{a}^{\prime}, \mathbf{1} \mathbf{b}$ and $\mathbf{1} \mathbf{k}^{\prime}$

ity of compounds 4l-n was lesser than that the lead compound I in all cell lines tested. Likewise, the data for compounds II, IV, 4I- $\mathbf{m}$ in three of the six cancer lines U-251, HCT-15 and SKLU-1 indicate that the cytotoxic effect was dependent of the kind of aromaticity of the substituent joined to C-2 (Table 4). These findings confirmed that the cytotoxic activity could be explained in terms of the distribution of electronic density across the ring joined to $\mathrm{C}-2$.

The cytotoxic activities of our most active compounds $\mathbf{4 d}$ and $\mathbf{4} \mathbf{j}$ were compared with those of the commercially available Topotecan, ${ }^{16)}$ Irinotecan, ${ }^{17)}$ Etoposide, ${ }^{18)}$ Tamoxifen, ${ }^{19)}$ and Cisplatin. ${ }^{20)}$ As shown in Table 3, compound 4d (3-OH) was ten times more active than cisplatin in the prostate PC-3 cell line, almost two thousand times more active than irinotecan in the colon HCT-15 cell line. In the lung SKLU-1 cell line, compound 4d (3-OH) was thirty-seven times more active than topotecan, six hundred forty-one times more active than irinotecan and seventy-six times more active than etoposide. Compound $\mathbf{4 j}$ (3-Cl) showed more activity in the U-251(CNS) cell line and leukemia K-562 cell line compared to the reference etoposide. Finally, compound $\mathbf{4 j}$ (3-Cl) showed a higher activity than tamoxifen in the breast cancer cell line MCF-7.

\section{Conclusion}

Compounds $\mathbf{4 a}-\mathbf{n}$ were synthetized through a practical synthetic route involving the van Leusen's pyrrole construction protocol and an intramolecular radical oxidative cyclization. The inhibitory activities of compounds $\mathbf{4 a}-\mathbf{n}$ were evaluated using six cancer cell lines. Our results reveal that the cytotoxic activity could be explained in terms of the distribution of electronic density across the ring joined to C-2. Also, the present study enabled the discovery of the novel 3-hydroxy $4 \mathbf{d}$ 
Table 2. Effects of Modifying the Cyclohexylmethylpiperazinyl Group on the Antiproliferative Activity ${ }^{a}$

\begin{tabular}{|c|c|c|c|c|c|c|c|}
\hline Compd. & $\mathbf{R}=$ & PC-3 & U-251 & K-562 & HCT-15 & MCF-7 & SKLU-1 \\
\hline $\mathbf{I}$ & & $0.16 \pm 0.01$ & $0.05 \pm 0.00$ & $0.16 \pm 0.01$ & $0.02 \pm 0.01$ & $5.58 \pm 0.04$ & $0.02 \pm 0.001$ \\
\hline $4 a^{\prime}$ & & $10.20 \pm 1.40$ & $11.10 \pm 0.70$ & $8.12 \pm 0.70$ & $11.40 \pm 0.70$ & $8.32 \pm 0.90$ & $7.98 \pm 0.40$ \\
\hline $4 a$ & & $6.39 \pm 0.50$ & $6.89 \pm 0.80$ & $3.45 \pm 0.20$ & $5.23 \pm 0.50$ & $7.26 \pm 0.60$ & $6.28 \pm 0.70$ \\
\hline $4 b$ & & N.A & N.A & N.A & N.A & N.A & N.A \\
\hline $4 c$ & & $1.23 \pm 0.10$ & $1.42 \pm 0.10$ & $1.07 \pm 0.08$ & $1.34 \pm 0.30$ & $1.09 \pm 0.10$ & $1.13 \pm 0.10$ \\
\hline
\end{tabular}

a) Results are expressed as $\mathrm{IC}_{50}$ values in units of $\mu \mathrm{M} \pm$ S.E. The values indicate the mean calculated from experiments conducted in triplicate. N.A.: this compound was not active. The bold numbers represent the highest activities of the compounds tested.

and 3 -chloro $\mathbf{4 j}$ derivatives pyrroloisoquinoline compounds, which displayed excellent cytotoxic activity. The $\mathrm{IC}_{50}$ values of these compounds were determined and were found to compare satisfactorily with those of the commercially available drugs topotecan, irinotecan, etoposide, tamoxifen, and cisplatin.

\section{Experimental}

Chemistry All reported melting points were measured in open capillaries using a Mel-Temp apparatus. ${ }^{1} \mathrm{H}-\mathrm{NMR}$ spectra were recorded on a Avance III HD $700 \mathrm{MHz}$ Brucker, Avance III HD $500 \mathrm{MHz}$ Brucker, Avance $400 \mathrm{MHz}$ Brucker, $300 \mathrm{MHz}$ Jeol Eclipse, Fourier $300 \mathrm{MHz}$ Brucker spectrometers in deuterated chloroform $\left(\mathrm{CDCl}_{3}\right)$ solutions using tetramethylsilane (TMS) as the internal standard $(\delta=0 \mathrm{ppm}),{ }^{14} \mathrm{C}-\mathrm{NMR}$ spectra were recorded at $75,100,125,150$ and $175 \mathrm{MHz}$ on the same instruments. The chemical shifts are reported in the $\delta$ scale in parts per million (ppm). The peak patterns are indicated as follows: s, singlet; $d$, doublet; $t$, triplet; $q$, quartet; $\mathrm{m}$, multiplet; brs, broad signal. The coupling constants $(J)$ are reported in Hertz (Hz). IR spectra were obtained on a Magna-IR spectrometer. Mass spectra were recorded on Jeol JEM-AX505HA spectrometer by electronic impact (EI) detection at $70 \mathrm{eV}$ for low-resolution and on a Jeol 5X102A mass spectrometer (Jeol Ltd.) with fast atom bombardment $(\mathrm{FAB}+)$ and EI ionization detection for high-resolution measurements.

General Procedure for Synthesizing the Pyrroles 2a'-n A solution containing the alkene $(2.6 \mathrm{mmol})$ and 1-(1-isocyanoethylsulfonyl)-4-methylbenzene (Me-TosMIC) $(0.6 \mathrm{~g}, 2.9 \mathrm{mmol})$ in $\mathrm{Et}_{2} \mathrm{O}-\mathrm{DMSO}(2: 1,15 \mathrm{~mL})$ was added dropwise to a suspension of $\mathrm{NaH}(0.23 \mathrm{~g}, 5.7 \mathrm{mmol}, 60 \%$ dispersion in mineral oil) in dry ether $(5 \mathrm{~mL})$. The mixture was stirred at room temperature for $1 \mathrm{~h}$, then $\mathrm{H}_{2} \mathrm{O}(15 \mathrm{~mL})$ was added dropwise and the product was extracted with EtOAc $(3 \times 30 \mathrm{~mL})$. The organic layer was washed with $\mathrm{H}_{2} \mathrm{O}$ and brine $(3 \times 10 \mathrm{~mL})$, dried with $\mathrm{Na}_{2} \mathrm{SO}_{4}$, and evaporated in vacuo. The residue was purified by flash column chromatography on silica gel to furnish the respective pyrrole. Physical and spectroscopic data of all compounds $\mathbf{2} \mathbf{a}^{\prime}-\mathbf{n}$ are reported in supplementary material.

General Procedure for the Synthesis of the $\mathrm{N}$-Alkylpyrroles $3 \mathbf{a}^{\prime}-\mathbf{n} \quad \mathrm{NaH}(0.2 \mathrm{~g}, 5.7 \mathrm{mmol}, 60 \%$ dispersion in mineral oil) was added portionwise to a solution of the corresponding pyrrole $(2.3 \mathrm{mmol})$ and 2-bromo-4,5-dimethoxyphenethyl 4-methyl benzenesulfonate $(1.9 \mathrm{~g}, 4.5 \mathrm{mmol})$ in dry DMSO $(10 \mathrm{~mL})$. The mixture was stirred at room temperature for $6 \mathrm{~h}$, EtOAc $(20 \mathrm{~mL})$ was added, and the solution was washed with water and brine $(3 \times 10 \mathrm{~mL})$. The organic layer was dried with $\mathrm{Na}_{2} \mathrm{SO}_{4}$ and evaporated in vacuo. The residue was purified by flash column chromatography on silica gel to furnish the respective $N$-alkylpyrrole. Physical and spectroscopic data of all compounds $3 \mathbf{a}^{\prime}-\mathbf{n}$ are reported in supplementary material.

General Procedure for Synthesizing the 5,6Dihydropyrrolo $[2,1-a]$ isoquinolines $4 a^{\prime}, 4 b, 4 c, 4 d^{\prime}, 4 e, 4 f$, $\mathbf{4 j}, \mathbf{4} \mathbf{k}^{\prime}, \mathbf{4} \mathbf{l}^{\prime}, \mathbf{4 m}, \mathbf{4 n}$ To a refluxing solution of the $N$-alkylpyrrole in degassed dry toluene $(10 \mathrm{~mL})$, a solution of $n-\mathrm{Bu}_{3} \mathrm{SnH}$ 
Table 3. Effects of meta-Substituent on 3-Phenyl Moiety on the Antiproliferative Activity and Comparison with the Activities of Commercially Available Drugs ${ }^{a)}$

\begin{tabular}{|c|c|c|c|c|c|c|c|}
\hline Compd. & $\mathbf{R}=$ & PC-3 & U-251 & K-562 & HCT-15 & MCF-7 & SKLU-1 \\
\hline I & & $0.16 \pm 0.01$ & $0.05 \pm 0.00$ & $0.16 \pm 0.01$ & $0.02 \pm 0.01$ & $5.58 \pm 0.04$ & $0.02 \pm 0.001$ \\
\hline II & & $18.15 \pm 0.60$ & $4.86 \pm 0.60$ & $76.78 \pm 7.30$ & $0.14 \pm 0.06$ & $25.20 \pm 2.00$ & $0.59 \pm 0.00$ \\
\hline III & & $21.20 \pm 1.20$ & $5.96 \pm 0.50$ & $2.50 \pm 0.80$ & $0.01 \pm 0.00$ & $1.30 \pm 0.10$ & $0.10 \pm 0.00$ \\
\hline $4 d$ & & $0.76 \pm 0.50$ & $6.12 \pm 0.40$ & $5.47 \pm 0.70$ & $0.01 \pm 0.00$ & $5.72 \pm 0.40$ & $0.05 \pm 0.01$ \\
\hline $4 e$ & & $3.26 \pm 0.10$ & $3.31 \pm 0.40$ & $2.65 \pm 0.10$ & $0.69 \pm 0.05$ & $2.35 \pm 0.20$ & $0.77 \pm 0.08$ \\
\hline $4 f$ & & $3.86 \pm 0.10$ & $3.17 \pm 0.30$ & $1.98 \pm 0.05$ & $2.53 \pm 0.20$ & $4.08 \pm 0.20$ & $2.93 \pm 0.08$ \\
\hline $4 \mathrm{~g}$ & & $8.26 \pm 1.00$ & $12.66 \pm 0.50$ & $8.28 \pm 1.10$ & $0.10 \pm 0.04$ & $13.98 \pm 0.70$ & $1.26 \pm 0.30$ \\
\hline $4 h$ & & $2.30 \pm 0.20$ & $2.50 \pm 0.40$ & $3.30 \pm 0.20$ & $1.90 \pm 0.20$ & $3.10 \pm 0.30$ & $1.70 \pm 0.10$ \\
\hline $4 i$ & & $2.20 \pm 0.09$ & $3.10 \pm 0.20$ & $1.30 \pm 0.20$ & $2.50 \pm 0.30$ & $1.70 \pm 0.07$ & $3.30 \pm 0.10$ \\
\hline $4 j$ & & $0.91 \pm 0.01$ & $0.37 \pm 0.04$ & $0.33 \pm 0.03$ & $0.25 \pm 0.02$ & $0.88 \pm 0.09$ & $0.76 \pm 0.07$ \\
\hline $4 k$ & & $22.90 \pm 0.90$ & $23.60 \pm 0.90$ & $5.20 \pm 1.20$ & $5.60 \pm 0.20$ & $57.70 \pm 1.00$ & $3.60 \pm 0.60$ \\
\hline Topotecan & & & & & $0.50 \pm 0.05$ & $0.10 \pm 0.02$ & $2.00 \pm 0.10$ \\
\hline Irinotecan & & & & & $33.09 \pm 3.40$ & & $34.62 \pm 2.30$ \\
\hline Etoposide & & & $1.70 \pm 0.30$ & $11.30 \pm 2.50$ & & & $4.10 \pm 0.60$ \\
\hline Tamoxifen & & & & & & $12.80 \pm 1.10$ & \\
\hline Cisplatin & & $8.30 \pm 0.70$ & $3.30 \pm 0.60$ & & & & \\
\hline
\end{tabular}

a) Results are expressed as $\mathrm{IC}_{50}$ values in units of $\mu \mathrm{M} \pm$ S.E. The values indicate the mean calculated from experiments conducted in triplicate. The bold numbers represent the highest activities of the compounds tested.

$(1.0 \mathrm{~mL}, 3.7 \mathrm{mmol})$ in toluene $(5 \mathrm{~mL})$ was added dropwise (syringe pump) over $7 \mathrm{~h}$. During that time, solid dilauroyl peroxide (DLP) was added portionwise $(1.49 \mathrm{~g}, 3.7 \mathrm{mmol}$, $0.11 \mathrm{~g} / 30 \mathrm{~min})$. The solvent was removed under reduced pressure and the crude residue was purified by flash column chromatography on silica gel. Hexane was first added to remove the $n-\mathrm{Bu}_{3} \mathrm{SnBr}$, then hexane-EtOAc- $\mathrm{Et}_{3} \mathrm{~N}(70: 25: 5$ to $50: 45: 5)$. Physical and spectroscopic data of all compounds $\mathbf{4} \mathbf{a}^{\prime}-\mathbf{n}$ are reported in supplementary material.

Cell Culture and Assay for Cytotoxic Activity Cell 
Table 4. Effects of Aromaticity of C-2 Substituent on the Antiproliferative Activity ${ }^{a}$

\begin{tabular}{|c|c|c|c|c|c|c|c|}
\hline Compd. & $\mathbf{R}=$ & PC-3 & U-251 & K-562 & HCT-15 & MCF-7 & SKLU-1 \\
\hline I & & $0.16 \pm 0.01$ & $0.05 \pm 0.00$ & $0.16 \pm 0.01$ & $0.02 \pm 0.01$ & $5.58 \pm 0.04$ & $0.02 \pm 0.00$ \\
\hline II & & $18.15 \pm 0.60$ & $4.86 \pm 0.60$ & $76.78 \pm 7.30$ & $0.14 \pm 0.06$ & $25.20 \pm 2.00$ & $0.59 \pm 0.00$ \\
\hline IV & & $8.47 \pm 0.23$ & $6.99 \pm 0.67$ & $4.07 \pm 0.49$ & $0.59 \pm 0.05$ & $7.41 \pm 0.09$ & $2.13 \pm 0.03$ \\
\hline 41 & & $10.50 \pm 0.24$ & $8.99 \pm 0.68$ & $6.50 \pm 0.67$ & $0.90 \pm 0.06$ & $13.60 \pm 0.60$ & $5.60 \pm 0.05$ \\
\hline $4 m$ & & $2.97 \pm 0.10$ & $8.67 \pm 0.10$ & $8.54 \pm 0.50$ & $1.72 \pm 0.20$ & $14.70 \pm 1.00$ & $6.76 \pm 0.09$ \\
\hline $4 n$ & & $21.70 \pm 0.20$ & $24.70 \pm 1.10$ & $9.10 \pm 0.90$ & $14.00 \pm 1.40$ & $23.70 \pm 1.00$ & $15.60 \pm 1.20$ \\
\hline
\end{tabular}

a) Results are expressed as $\mathrm{IC}_{50}$ values in units of $\mu \mathrm{M} \pm$ S.E. The values indicate the mean calculated from experiments conducted in triplicate. The bold numbers represent the highest activities of the compounds tested.

culture and assay for activity PC-3, U-251, K-562, HCT-15, MFC-7, and SKUL-1, were supplied by The National Cancer Institute (NCI), U.S.A. The cytotoxicity of tumors cells with the test compounds was determined using the protein-binding dye sulforhodamine B (SBR) in microculture assay to measure cell growth. ${ }^{21)}$ The cell lines were cultured in RPMI-1640 (Sigma Chemical Co., Ltd., St. Louis, MO, U.S.A.) supplemented with $10 \%$ fetal bovine serum which was purchased from Invitrogen Corporation, $2 \mathrm{mM}$ L-glutamine, 10000 units $/ \mathrm{mL}$ of penicillin G, $10000 \mu \mathrm{g} / \mathrm{mL}$ streptomycin and $0.25 \mu \mathrm{g} / \mathrm{mL}$ Fungizone (Gibco). They were maintained at $37^{\circ} \mathrm{C}$ in a $5 \% \mathrm{CO}_{2}$ atmosphere with $95 \%$ humidity. For the assay, $5104 \mathrm{cell} / \mathrm{mL}$ (K-562, MCF-7), $7510 \mathrm{cell} / \mathrm{mL}$ (U-251, PC-3) and $10104 \mathrm{cell} / \mathrm{mL}$ (SKLU-1, HCT-15), and $100 \mathrm{~mL} /$ well of these cells suspension was seeded in a 96-well microtiter plates and incubated to allow for cell attachment. After $24 \mathrm{~h}, 100 \mu \mathrm{L}$ of each test compounds and positive substances were added to each well. Later $48 \mathrm{~h}$, adherent cell cultures were fixed in situ by adding $50 \mathrm{~mL}$ od cold $50 \%$ (w/v) trichloroacetic acid (TCA) and incubated for $60 \mathrm{~min}$ at $4^{\circ} \mathrm{C}$. The supernatant was discarded and the plates were washed three times with water and air dried. Cultured fixed with TCA were stained for 30 min with $100 \mu \mathrm{L}$ of $0.4 \%$ SRB solution. Protein-bounded dye was extraxted with $10 \mathrm{~mm}$ unbuffered tris base and the optical densities were read on a Microplate Reader Synergy HT (Elx 808, BIOTEK Instruments, Inc., U.S.A.), with a test wavelength of $515 \mathrm{~nm}$. Results were expressed as $\mathrm{IC}_{50}$ values, they were calculated according to the protocol of Monks, were a dose-response curve was plotted for each compound, and the concentration giving $50 \%$ inhibition $\left(\mathrm{IC}_{50}\right)$ was estimated from non-linear regression equations. The $\mathrm{IC}_{50}$ value (mean standard error (S.E.). ${ }^{22)}$

Acknowledgments This work was supported by Cona- cyt (Consejo Nacional de Ciencia y Tecnología), Project No. 131295 and Fellowship No. 223141. Financial support from the Dirección General de Asuntos del Personal Académico (DGAPA), Universidad Nacional Autónoma de México (UNAM) (project PAPIIT IN213407) is gratefully acknowledged. We also thank Q. R. Patiño, Dra. N. Esturau, Q. A. Peña, M. C. E. Huerta, Dra. B. Quiroz, and Dra. C. García, I. Q. L. Velasco, Dr. J. Pérez, and Dra. V. Labastida (Centro de Investigaciones Químicas (CIQ), Universidad Autónoma del Estado de Morelos (UAEM)) for technical support. During the experimentation process Rosa María Chávez Santos was a Conacyt Graduate Scholarship holder (No. 223441).

Conflict of Interest The authors declare no conflict of interest.

Supplementary Materials The online version of this article contains supplementary materials

\section{References}

1) Ferlay J., Soerjomataram I., Dikshit R., Eser S., Mathers C., Rebelo M., Parkin D. M., Forman D., Bray F., Int. J. Cancer, 136, E359E386 (2015)

2) Fitzmaurice C., Dicker D., Pain A., Hamavid H., Moradi-Lakeh M., MacIntyre M. F., Allen C., Hansen G., Woodbrook R., Wolfe C., Hamadeh R. R., Moore A., Werdecker A., Gessner B. D., Te Ao B., McMahon B., Karimkhani C., Yu C., Cooke G. S., Schwebel D. C., Carpenter D. O., Pereira D. M., Nash D., Kazi D. S., De Leo D., Plass D., Ukwaja K. N., Thurston G. D., Yun Jin K., Simard E. P., Mills E., Park E. K., Catalá-López F., deVeber G., Gotay C., Khan G., Hosgood H. D. 3rd, Santos I. S., Leasher J. L., Singh J., Leigh J., Jonas J. B., Sanabria J., Beardsley J., Jacobsen K. H., Takahashi K., Franklin R. C., Ronfani L., Montico M., Naldi L., Tonelli M., Geleijnse J., Petzold M., Shrime M. G., Younis M., Yonemoto N., Breitborde N., Yip P., Pourmalek F., Lotufo P. A., Esteghamati A., 
Hankey G. J., Ali R., Lunevicius R., Malekzadeh R., Dellavalle R., Weintraub R., Lucas R., Hay R., Rojas-Rueda D., Westerman R., Sepanlou S. G., Nolte S., Patten S., Weichenthal S., Abera S. F. Fereshtehnejad S. M., Shiue I., Driscoll T., Vasankari T., Alsharif U., Rahimi-Movaghar V., Vlassov V. V., Marcenes W. S., Mekonnen W., Melaku Y. A., Yano Y., Artaman A., Campos I., MacLachlan J., Mueller U., Kim D., Trillini M., Eshrati B., Williams H. C., Shibuya K., Dandona R., Murthy K., Cowie B., Amare A. T., Antonio C. A., Castañeda-Orjuela C., van Gool C. H., Violante F., Oh I. H., Deribe K., Soreide K., Knibbs L., Kereselidze M., Green M., Cardenas R., Roy N., Tillmann T., Li Y., Krueger H., Monasta L., Dey S., Sheikhbahaei S., Hafezi-Nejad N., Kumar G. A., Sreeramareddy C. T., Dandona L., Wang H., Vollset S. E., Mokdad A., Salomon J. A., Lozano R., Vos T., Forouzanfar M., Lopez A., Murray C., Naghavi M., Global Burden of Disease Cancer Collaboration, JAMA Oncol., 1, 505-527 (2015).

3) Reyes-Gutiérrez P. E., Camacho J. R., Ramírez-Apan M. T., Osornio Y. M., Martínez R., Org. Biomol. Chem., 8, 4374-4382 (2010).

4) Bauser M., Ergüden J. K., Flubacher D., Naab P., Repp T. H., Stoltefuss J., Burkhardt N., Sewing A., Schauer M., Schlemmer K. H., Weber O., Boyer S. J., Miglarese M., Ying S., Niewöhner U., 3-Substituted pyrrolo[2.1- $a$ ] isoquinoline derivatives. WO2003014 117A1, PCT/US2002/024877. http://google.com/patents/WO20030141 $17 \mathrm{~A} 1 \mathrm{cl}=\mathrm{en}(2003)$

5) Sano S., Matsumoto T., Nanataki H., Tempaku S., Nakao M., Tetrahedron Lett., 55, 6248-6251 (2014).

6) Heck R., Metals Rev., 24, 58-63 (1980).

7) Valeur E., Bradley M., Chem. Soc. Rev., 38, 606-631 (2009).
8) van Leusen A. M., Siderius H., Hoogenboom B. E., van Leusen D., Tetrahedron Lett., 13, 5337-5340 (1972).

9) Guerrero M. A., Cruz-Almanza R., Miranda L. D., Tetrahedron, 59, 4953-4958 (2003).

10) Amatore C., Jutand A., Acc. Chem. Res., 33, 314-321 (2000).

11) Xia Y. M., Xia J., Chai C., Chem. Pap., 68, 384-391 (2014).

12) Horita K., Yoshioka T., Tanaka T., Oikawa Y., Yonemitsu O., Tetrahedron, 42, 3021-3028 (1986).

13) Nakhi A., Rahman M. S., Archana S., Kishore R., Seerapu G. P. K., Kumar K. L., Haldar D., Pal M., Bioorg. Med. Chem. Lett., 23, 4195-4205 (2013)

14) Sajiki H., Kuno H., Hirota K., Tetrahedron Lett., 38, 399-402 (1997).

15) Lima L. M., Barreiro E. J., Curr. Med. Chem., 12, 23-49 (2005).

16) Khalife R., Hodroj M., Fakhoury R., Rizk S., Planta Med., 82, 312-321 (2016).

17) Phelps M. A., Sparreboom A., J. Clin. Pharmacol., 32, 2287-2289 (2014).

18) Pommier Y., Leo E., Zhang H. L., Marchand C., Chem. Biol., 17, 421-433 (2010).

19) Hackshaw A., Roughton M., Forsyth S., Monson K., Reczko K., Sainsbury R., Baum M., J. Clin. Oncol., 29, 1657-1663 (2011).

20) Florea A. M., Büsselberg D., Cancers, 3, 1351-1371 (2011).

21) Musser J. H., Kreft A., J. Med. Chem., 35, 2501-2524 (1992).

22) Monks A., Scudiero D., Skehan P., Shoemaker R., Paull K., Vistica D., Hose C., Langley J., Cronise P., Vaigro-Wolff A., GrayGoodrich M., Campbell H., Mayo J., Boyd M., J. Natl. Cancer Inst., 83, 757-766 (1991). 